UDC 32.019 .51

Submitted: 17.01.2021

LBC 66.3(2Poc)

Accepted: 01.02.2021

\title{
DEMOGRAPHIC THREATS TO NATIONAL SECURITY IN THE POLITICAL DISCOURSE OF THE RUSSIAN FEDERATION (1992-2019) ${ }^{1}$
}

\author{
Ekaterina N. Vasilieva \\ Volgograd State University, Volgograd, Russian Federation \\ Tamara K. Rostovskaya \\ Institute for Demographic Research of the Federal Center of Theoretical and Applied Sociology \\ of the Russian Academy of Sciences, Moscow, Russian Federation \\ Ebulfez Süleymanlý \\ Üsküdar University, Istanbul, Turkey
}

\begin{abstract}
Introduction. Population growth in the world is uneven: while in some countries the population has been growing for a long time (China, India), in Russia and in many EU and BRIC countries, the birth rate has been declining in recent years; and if this does not affect the population, then only by increasing life expectancy and migration. Abrupt changes - both growth and decline - in the population are a threat to the national security of the state. The purpose of this work is to evaluate the effectiveness of political management (strategies and tools) aimed at solving demographic problems and increasing the birth rate in the Russian Federation, as well as to identify the stages of the formation of demographic policy in the Russian Federation in 1992-2019. Methods and materials. Based on the qualitative analysis of normative documents, the frame analysis of speeches of political leaders the main factors that influenced the coverage of demographic problems are revealed (the authors used official electronic versions of the following publications: "Sobranie Zakonodatelstva Rossiyskoy Federatsii" (Collection of Legislation of the Russian Federation) and "Byulleten normativnykh aktov federalnykh organov ispolnitelnoy vlasti" (Bulletin of Normative Acts of Federal Executive Authorities). Analysis. The proposed research strategy allowed identifying demographic threats to national security articulated by political actors and $\overrightarrow{7}$ presented in official documents, statements of officials, as well as to compare the political decisions taken in the ণิ Russian Federation with the decisions taken in some European countries. Strategic documents that ensure $\&$ national security of the Russian Federation by including the demographic agenda in political discourse are considered as a tool of political management. Results. The article assesses the effectiveness of political management in solving demographic problems and increasing the birth rate in the Russian Federation, identifies the stages of the formation of demographic policy in the Russian Federation in 1992-2019, as well as the features of the articulation of demographic problems in the political discourse of Russia, and describes demographic threats. The analysis of the regulatory framework as a tool for political management, demographic threats prevention, as well as the basis of the state strategy for increasing the birth rate in the Russian Federation allowed identifying policy decisions that can be used to develop new measures within the framework of programs to increase the birth rate in the Russian Federation.
\end{abstract}

Key words: national security, demographic threats, political management, political decisions, strategy, social policy, demographic policy, birth rate, migration, measures of social support of the population.

Citation. Vasilieva E.N., Rostovskaya T.K., Süleymanlý E. Demographic Threats to National Security in the Political Discourse of the Russian Federation (1992-2019). Vestnik Volgogradskogo gosudarstvennogo universiteta. Seriya 4. Istoriya. Regionovedenie. Mezhdunarodnye otnosheniya [Science Journal of Volgograd State University. History. Area Studies. International Relations], 2021, vol. 26, no. 2, pp. 255-272. (in Russian). DOI: https://doi.org/10.15688/jvolsu4.2021.2.20 


\title{
ДЕМОГРАФИЧЕСКИЕ УГРОЗЫ НАЦИОНАЛЬНОЙ БЕЗОПАСНОСТИ В ПОЛИТИЧЕСКОМ ДИСКУРСЕ РФ (1992-2019) ${ }^{1}$
}

\author{
Екатерина Николаевна Васильева
}

Волгоградский государственный университет, г. Волгоград, Российская Федерация

Тамара Керимовна Ростовская

Институт демографических исследований ФНИСЦ РАН, г. Москва, Российская Федерация

\author{
Абульфаз Сулейманлы \\ Ускюдарский университет, г. Стамбул, Турция
}

\begin{abstract}
Аннотация. Введение. Распределение народонаселения в мире неравномерно: если в одних странах численность населения на протяжении длительного времени растет (Китай, Индия), то в России и во многих странах ЕС и БРИКС на протяжении последних лет рождаемость снижается, а если это не отражается на численности населения, то только за счет увеличения продолжительности жизни и миграции. Резкие изменения - как рост, так и снижение численности населения - становятся угрозой национальной безопасности государства. Целью данной работы является оценка эффективности политического управления (стратегии и инструментов), направленного на решение демографических проблем и увеличение рождаемости в РФ, а также выделение этапов формирования демографической политики в РФ в 1992-2019 годы. Методы и материалы. В работе использован качественный анализ нормативных документов, в частности фрейм-анализ текстов выступлений политических лидеров, что позволило выявить основные факторы, повлиявшие на политические решения в области демографической политики (для работы использовались официальные электронные версии следующих изданий: издание «Собрание Законодательства Российской Федерации» и издание «Бюллетень нормативных актов федеральных органов исполнительной власти»). Анализ. Предложенная исследовательская стратегия позволила выделить демографические угрозы национальной безопасности, артикулированные политическими субъектами и представленные в официальных документах, заявлениях официальных лиц, а также сравнить политические решения, принимаемые в РФ и некоторых европейских странах. Стратегические документы, обеспечивающие национальную безопасность РФ посредством включения демографической повестки в политический дискурс, рассматриваются как инструмент политического управления. Результаты. В работе дана оценка эффективности политического управления в области решения демографических проблем и увеличения рождаемости в РФ, выделены этапы формирования демографической политики в РФ в 1992-2019 гг,, а также особенности артикуляции демографических проблем в политическом дискурсе России, охарактеризованы демографические угрозы. Анализ нормативной базы как инструмента политического управления, предотвращения демографических угроз, а также основы государственной стратегии повышения рождаемости в РФ позволил определить политические решения, которые могуг быть использованы для разработки новых мер в рамках программ увеличения рождаемости в Российской Федерации. Вклад авторов. Е.Н. Васильева сделала выборку нормативных документов за 1992-2019 гг. и провела их анализ на предмет выстраивания стратегии принятия управленческих решений в области национальной безопасности и противодействия демографическим угрозам, представила данные европейских исследований. Т.К. Ростовская выстроила теоретическую схему исследования национальной безопасности, социальной и демографической политики в РФ, охарактеризовала демографические исследования, проведенные в РФ в 1992-2019 годы. А. Сулейманлы разработал методику проведения анализа документов, уточнил прочтение нормативных документов.

Ключевые слова: национальная безопасность, демографические угрозы, политическое управление, политические решения, стратегия, социальная политика, демографическая политика, рождаемость, миграция, меры социальной поддержки населения.
\end{abstract}

Цитирование. Васильева Е. Н., Ростовская Т. К., Сулейманлы А. Демографические угрозы национальной безопасности в политическом дискурсе РФ (1992-2019) // Вестник Волгоградского государственного университета. Серия 4, История. Регионоведение. Международные отношения. - 2021. - Т. 26, № 2. C. 255-272. -DOI: https://doi.org/10.15688/jvolsu4.2021.2.20 
Введение. Одним из самых актуальных в рамках политики и экономики является вопрос об эффективности политического управления для решения стоящих перед государством задач. Последние можно структурировать, выделив макро-, мезо- и микроуровни, но на каждом из них функция обеспечения национальной безопасности является одной из приоритетных, базовых, как и функция распределения общественных благ.

Национальная безопасность Российской Федерации (согласно Указу Президента РФ от 31.12.2015 № 683) - состояние защищенности личности, общества и государства от внутренних и внешних угроз, при котором обеспечиваются реализация конституционных прав и свобод граждан Российской Федерации [41]. Формулировка понятия национальной безопасности в современных нормативных документах существенно не меняется с 1992 г. [6]. Однако достаточно серьезно трансформировались и расширились представления об угрозах национальной безопасности и задачах, стоящих перед Советом безопасности Российской Федерации, межведомственными комиссиями и аппаратом Совета безопасности Российской Федерации, в целом перед Правительством РФ.

Угрозы безопасности на разных уровнях будут серьезно отличаться по масштабу последствий. В начале XX в. было проведено несколько исследований эффективности политического управления в области решения демографических проблем $[1 ; 10 ; 44]$. Задачи, стоящие перед государством в период депопуляции, должны решаться комплексно, так как убыль населения напрямую сказывается на ситуации. Во-первых, сокращается призыв в армию, что несет серьезную опасность защиты государственных границ. Во-вторых, возможны смещения национального состава на- селения, что может привести к межнациональной напряженности. В-третьих, снижается плотность населения в отдаленных от центральной России регионах, что влечет экономические потери, связанные с неэффективным использованием территорий. В-четвертых, наблюдается уменьшение бюджета страны за счет снижения доли экономически активного населения, а вытекающая проблема - недофинансирование пенсионной системы РФ. Можно привести и другие примеры угроз как внешней, так и внутренней безопасности, которые являются последствием стремительного сокращения населения.

В Российской Федерации существенное сокращение населения началось с 1992 года. Предыдущие периоды депопуляции были обусловлены Первой мировой войной, гражданской войной, голодом и репрессиями 1930-х гг., Второй мировой войной - историческими процессами, результаты которых стали основой негативных демографических прогнозов и обусловили убыль населения. Положительный естественный прирост некоторое время сохранялся в СССР за счет коэффициента суммарной рождаемости условного поколения женщин (2,8 в 1950 г.), однако уже к концу 70-х гг. показатель опустился до 1,9 рождений на одну женщину. А в 1979-1980 гг. продолжительность жизни в нашей стране достигла минимума - 61,5 года у мужчин, 73 года у женщин. [4, с. 105-108]. Далее ситуация только усугублялась (см. рисунок).

В 2019 г. в России демографический кризис все еще не преодолен, именно поэтому необходимо проанализировать исторические предпосылки формирования современной социально-демографической политики, расширить представления о международном опыте формирования демографической политики как основы

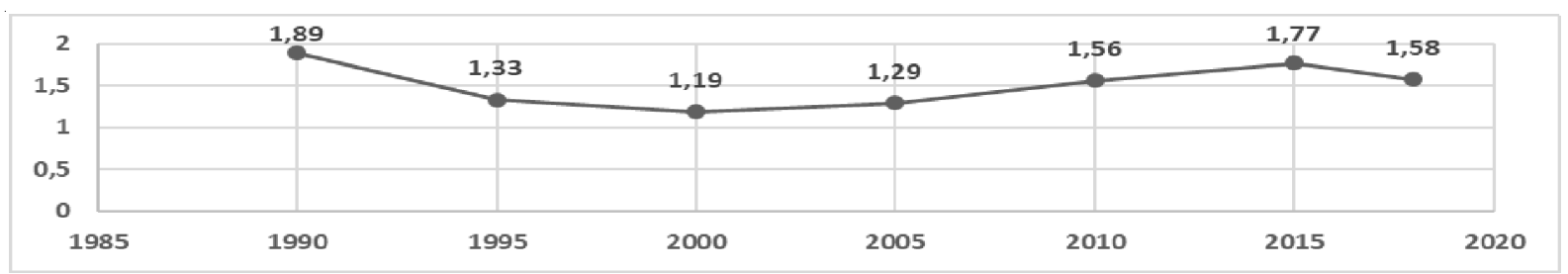

Изменение коэффициента суммарной рождаемости условного поколения женщин в 1985-2020 гг.

Change in the total birth rate of the conditional generation of women in 1985-2020

Примечание. Составлено авторами на основе: [5, с. 13]. 
безопасности государства, уточнить на основе анализа официальных нормативных документов как источника фактологической информации причины сложившейся ситуации, что позволит систематизировать актуальные данные для дальнейшего изучения важнейших этапов новейшей истории Российской Федерации.

Методы и материалы. В работе поступательно рассматриваются этапы артикуляции демографических проблем в политическом дискурсе России. Основным методом исследования является качественный анализ контента нормативных документов, а также фрейм-анализ текстов выступлений политических лидеров Российской Федерации [3]. Основными источниками информации являются электронные версии официального издания «Собрание Законодательства Российской Федерации» и официального издания «Бюллетень нормативных актов федеральных органов исполнительной власти» [21]. Предварительно выделены базовые показатели ухудшающихся демографических прогнозов (смысловые оси исследования) - коэффициент суммарной рождаемости; смертность населения; миграционный прирост. Анализ нормативных документов начинался с поиска следующих ключевых слов: «семья», «дети», «молодежь», «женщины», «материнство», «рождаемость», «смертность», «миграция», «демография», «здоровье», «депопуляция», «безопасность». Фиксировался контекст нормативных документов - финансовые документы, декларативные, стратегические. Использовался фрейманализ текста, то есть в тексте приводятся цитаты, позволяющие делать выводы об устойчивых риторических практиках, связанных с демографическими проблемами и безопасностью государства. Предложенная исследовательская стратегия позволяет выделить этапы формирования демографической политики в РФ в 1992-2019 годы. Полученная информация сопоставляется с демографической политикой некоторых стран ЕС, что позволяет наметить перспективные направления артикуляции политическими субъектами демографической проблематики, а также оптимизировать государственное управление в области стабилизации демографической ситуации в контексте безопасности Российской Федерации.
Анализ. Несмотря на поступательно ухудшающуюся с 1960-1970-х гг. демографическую ситуацию, депопуляционные проблемы практически не обсуждались в политическом дискурсе до 1993 г., так как негативные тенденции были скрыты позитивными итогами введения в начале 80-х гг. мер помощи семьям с детьми. Коэффициент суммарной рождаемости вырос не только за счет календарных сдвигов в сроках рождения детей, но и за счет увеличения детности. О.Д. Захарова отмечает, что изменения рождаемости носили кратковременный характер, с 1987-1988 гг. началось новое снижение рождаемости [7, c. 46]. Не менее остро стояли вопросы здоровья и смертности населения. А.Е. Иванова отмечает, что к концу 80-х гг. объемы оказания медицинских услуг значительно выросли, но экстенсивный рост при отсутствии должного финансирования привел к снижению качества медицинского обслуживания, а экономическая структура стала неблагоприятной [8, с. 53]. Е. Красинец, Н. Баринова, Е. Тюрюканова приводят следующие статистические данные - в 1991 г. естественный прирост населения составил всего 0,7 чел. в расчете на 1 тыс. населения (в 1990 г. -2,2 чел.) [9, с. 35]. В.Н. Архангельский в публикациях 19931994 гг. говорит о кризисном состоянии института семьи, который перестал выполнять свою основную функцию, сформировавшаяся малодетность российской семьи стала началом депопуляции населения [2, с. 115]. Таким образом, важным этапом в постановке демографических вопросов на правительственном уровне стало обсуждение демографических проблем в научном сообществе, большое значение сыграл сформированный в 1988 г. на базе Академии Наук СССР Центр демографии и экологии человека Института народнохозяйственного прогнозирования РАН.

Контент-анализ электронных версий официального издания «Собрание Законодательства Российской Федерации» и официального издания «Бюллетень нормативных актов федеральных органов исполнительной власти» показывает, что одним из первых документов, подготовленных к работе в 1992-1993 гг., является Постановление Правительства РФ об утверждении Положения о Межведомственной комиссии по социально-демографическим 
вопросам [22]. Еще через несколько месяцев Указом Президента Российской Федерации была создана Комиссия по вопросам женщин, семьи и демографии при Президенте Российской Федерации [38], в состав которой вошел руководитель центра демографии и экологии человека Института народно-хозяйственного прогнозирования Российской академии наук А.Г. Вишневский и другие научные и административные работники. Целью работы комиссии стало содействие проведению научных исследований в области демографии и формирование необходимой информационной базы для принятия управленческих решений.

К 1994 г. сложилось понимание, что повысить суммарный коэффициент рождаемости в короткие сроки не удастся, а перед Правительством РФ стоят задачи регулирования миграции: «Предполагается миграция примерно 400 тыс. россиян из Закавказья и 2,9 млн из Средней Азии, переселенцев с Северного Кавказа ожидается около 600 тыс. чел., из государств Балтии может выехать 120-150 тыс. человек», - выводы, вошедшие в Федеральную миграционную программу [33]. Миграционный прирост беженцев и переселенцев из стран бывшего СССР позволил немного отложить негативные статистические тенденции, снижение численности населения.

Демографическая риторика, включенная в нормативные документы, имеет негативные коннотации: «Депопуляиия охватывает все большее количество территорий, усиливается проиесс старения населения, увеличивается смертность детей и мужчин трудоспособного возраста», - декларируется в документе «Основные направления социальной политики Правительства Российской Федерации на 1994 год» в негативных фреймрамках [22]. Финансирование поставленных задач осуществлялось за счет федеральных программ «Молодежь России» [31], «Дети России» (подпрограммы «Дети - инвалиды», «Дети - сироты», «Дети Севера», «Дети Чернобыля», «Планирование семьи», «Развитие индустрии детского питания в РСФСР на 1991-1995 годы») [43].

В начале 1996 г. руководство страны было вынуждено признать ухудшение ситуации: «...приостановлены строительство и реконструкиия ряда специализированных предприятий по производству детского питания〉, - было официально заявлено в Указе Президента Российской Федерации от 19.02.1996 № 210 «О продлении действия президентской программы “Дети России”» [39].

«Кризис»- основной фрейм нормативных документов данного периода: «Несмотря на мизерный размер ежемесячного пособия на ребенка, принимаемые Правительством Российской Федерации меры кардинально не меняют сложившегося положения, что способствует обострению сочиально-политической напряженности в стране»,- обозначено в Постановлении от 16.02.1996 № 90-II ГД [11].

В 1996 г. начата управленческая работа по формированию механизмов помощи семьям в обеспечении жильем: «Oстрота жилищной проблемы не снизилась. Насущно необходимым стали повышение сочиальной направленности жилищной реформы, разработка дополнительных мер государственной поддержки определенных соииальных групп населения. Это касается, прежде всего, малоимущих граждан, молодых и многодетных семей...», - отмечено в Указе Президента Российской Федерации от 29.03.1996 № 431 [40].

Артикуляция демографических проблем в этот период не ведется в публичном пространстве (в это время на повестке экономические новости и обсуждение локальных военных конфликтов), но постепенно включается в повестку заседаний Правительства РФ, формулируется в нормативных документах. В Указе Президента Российской Федерации от 14.05.1996 № 712 [37] ставится задача изучения проблем российских семей с финансированием соответствующих научных исследований.

Управление демографическими вопросами переходит на региональный уровень [32], а также на уровень органов местного самоуправления [19]. Для уточнения положений Федеральной миграционной программы теперь привлекаются эксперты из числа специалистов Центра социальной демографии Института социологии Российской академии наук, Института проблем занятости Российской академии наук и Центрального института труда, общественные объединения, занимающиеся проблемами миграции [17]. 
Обсуждение доклада председателя Комитета Государственной Думы по делам женщин, семьи и молодежи А.В. Апариной фиксируется в нормативных документах: «Существенно ухудшается здоровье граждан, растет материнская и детская смертность, увеличивается число больных детей, детей-инвалидов, детей-сирот и детей, оставшихся без попечения родителей» [12]. Активный поиск механизмов решения демографических проблем лежит в основе роста числа финансируемых социальных программ, укреплении системы социального обслуживания семьи и детей и программы переселения российских немцев.

Насыщение политического дискурса новым контентом происходит постепенно, и к 1997 г. начинает формироваться общая повестка, в которую включены проблемы детей, молодежи, молодой семьи и российской семьи: «Эффективная реализация основных направлений в области государственной молодежной политики должна привести $\kappa$ выравниванию демографической ситуаичи в стране, улучшению жилищных и соичиальных условий молодежи и молодых семей, повышению уровня доходов...,,заявлено в программе Правительства Российской Федерации «Структурная перестройка и экономический рост в 1997-2000 годах» [20]. Начинают использоваться новые инструменты - продлеваются целевые программы поддержки российских детей, детей-беженцев и вынужденных переселенцев. Утверждается план мероприятий Правительства Российской Федерации по реализации Программы социальных реформ в Российской Федерации на период 1996-2000 гг., в котором ставится задача разработать концепцию программы действий по выводу Российской Федерации из демографического кризиса [18].

Впервые демографическая проблема заявлена как проблема национальной безопасности государства в обращении Государственной Думы Федерального Собрания Российской Федерации к Президенту Российской Федерации в связи с принятием Всемирной декларации по здравоохранению: «Население России сокращается. Демографическая проблема переросла из проблемы региональной и этнической в проблему начио- нальной безопасности государства» [13], в этом же документе констатируется, что проблема откладывалась, перспективы ее решения связывались со стабилизацией экономического положения в стране, но стабилизация экономического положения не сказалась позитивно на рождаемости.

В то же время миграционные проблемы решаются неэффективно, негативный фрейм можно зафиксировать, обратившись к тексту документа «О деятельности Федеральной миграционной службы России по реализации миграционной политики»: «Факты свидетельствуют, что большинство российских соотечественников, возвратившихся в Россию, находятся в отчаянном положении: без жилья, работы, средств к существованию. <..> Они вынуждены повторно терпеть унижения на своей исторической родине» [14]. Негативные тенденции отражены и в иных документах: «Не удается добиться существенного повышения рождаемости. Остается высокой материнская и младенческая смертность» [15].

Качественный анализ нормативных документов 1992-1999 гг. позволяет определить данный временной промежуток как первый этап формирования демографической политики в контексте стратегии государственного управления и обеспечения безопасности российского государства, основным фреймом можно назвать артикуляцию угроз, которые спровоцированы снижением числа населения. С 2000 г. начинается новый этап формирования смыслов - популяризация демографических угроз национальной безопасности РФ. В Концепции национальной безопасности Российской Федерации отмечено: «Последствиями глубокого социального кризиса являются резкое сокращение рождаемости и средней продолжительности жизни в стране, деформачия демографического и сочиального состава общества» [36].

Впервые в 2000 г. В.В. Путин в ежегодном послании Федеральному Собранию Российской Федерации открыто говорит о том, что «численность населения страны в среднем ежегодно уменьшается на 750 тысяч человек. $<\ldots>$ Если нынешняя тенденция сохранится, выживаемость нации окажется под угрозой. $<\ldots>$ Сегодня демографическая ситуа- 
ция - одна из тревожных» [23]. Таким образом, демографическая повестка становится основной политической задачей, выходит за рамки экспертных докладов. Стратегическая задача поставлена - Правительство Российской Федерации начинает разработку концепции демографической политики Российской Федерации на период до 2015 г. [27], принимается Концепция охраны здоровья населения Российской Федерации на период до 2005 г. [29], продолжается финансирование федеральных целевых программ по улучшению положения детей в Российской Федерации на 2001-2002 годы.

С этого момента растет плотность, насыщенность текста демографическими понятиями, а к 2005 г. меняется фрейм нормативных документов - это не констатация демографических угроз, а выстраивание жестких механизмов государственного управления по реализации поставленных задач, что, с одной стороны, своевременно, с другой - меры реализуются с опозданием, решения разрабатываются с опорой на опыт европейских стран.

Сложность и противоречивость демографической ситуации в регионах мира актуализируют проведение исследований, направленных на поиск эффективных механизмов регулирования демографической политики. Значимый вклад в теорию демографического поведения привнесли концепции гендерного равенства, позволяющие связать воедино стратегии социально-экономической и демографической политики. М. Чжоу и М. Кан (M. Zhou, M.-Y. Kan) [54] сопоставляют уровень рождаемости и трудовую занятость мужчин и женщин с 1991 по 2017 г. в Великобритании (периоды с 1991 по 2000 г., с 2001 по 2008 г., с 2009 по 2017 г.). С 1992 по 2000 г. в России не было возможности проводить столь значимые эмпирические замеры, поэтому для построения прогнозных моделей использовались в основном статистические данные. Выводы, сделанные британскими социологами о положительном влиянии модели эгалитарной семьи на рождаемость, способствовали тому, что в сентябре 2010 г. Министерство образования Великобритании приняло нормативные документы, чтобы высвободить матерям время на работу. Для матерей, чьим детям от 3 до 4 лет, оно предоставило 570 часов в год бесплатного ухода за детьми, а с 2013 г. - и для 2-летних детей из неблагополучных семей [52].

Е. Божуан и К. Бергаммер (Е. Beaujouan, C. Berghammer) исследуют «разрыв рождаемости» - разницу между желаемым и фактическим числом детей у женщин 40 лет в 19 европейских странах и США [46]. Результаты проведенного ими исследования показывают, что женщины имеют в среднем меньше детей, чем планировали, и чаще, чем предполагалось, остаются бездетными (чем выше уровень образования женщины, тем выше разрыв между желаемым и фактическим числом детей). Если на фактическую рождаемость влияют «конкурирующие цели», занятость женщины, совместимость работы и семьи, то в представлениях об оптимальном количестве детей отражаются ценностные ориентации, складывающиеся под влиянием культуры региона проживания, семейного опыта женщины и т. д. Е. Божуан и К. Бергаммер выявили существенные различия в планировании семьи между женщинами Южной и Западной Европы, что определяется качеством инфраструктуры, позволяющей облегчить заботу о детях (доступность детских садов, хорошо оплачиваемый отпуск по уходу за ребенком оптимальный по продолжительности, то есть такой, который не позволит женщине потерять профессиональные навыки).

Э. Божуан и А. Солаз (Е. Beaujouan, A. Solaz) [47] исследуют влияние родительской семьи на поведение детей, вступивших в фертильный возраст, то есть речь о преемственности демографического поведения, механизмах передачи фертильности (на эмпирических данных Франции в XX в.). И приходят к выводу, что во Франции в XX в. размер родительской семьи, количество братьев и сестер по-прежнему являются определяющими факторами принятия решения о количестве детей в семье. Важен для государственного управления по вопросам формирования демографической политики вывод авторов о позитивном влиянии трехдетных семей на число рождений в следующем поколении, в этом случае уменьшение количества рождений или не происходит, или рождается двое детей, то есть сохраняется замещение населения.

А. Лебано и Л. Джеймисон (А. Lebano, L. Jamieson) [51] исследуют рождаемость в 
Италии и Испании, странах с наименьшим коэффициентом рождаемости в ЕС (1,34 против среднего по ЕС 1,6), которая снижается в течение 40 лет за счет трансформации демографического поведения поколений с 1935 по 1975 г. рождения. Авторы связывают это с отложенными рождениями - 31 год в Италии и 30,8 года в Испании против среднего показателя по ЕС - 29 лет, а также с увеличением доли матерей, чьи первые роды приходятся на возраст 40 лет и старше. Отложенное рождение приводит к снижению вероятности иметь более одного ребенка и к биологически обусловленной (недобровольной) бездетности. По результатам обработки текстов качественных глубинных интервью А. Лебано и Л. Джеймисон делают вывод о неуверенности молодежи в завтрашнем дне, обусловленной недостатком финансовых средств, недоверием работодателей к женщинам фертильного возраста, непростой ситуацией на рынке труда, невозможностью совмещать семейные обязанности и работу при ориентации на ответственное родительство или неуверенностью в собственных способностях воспитать ребенка.

А.-3. Дувандер и М. Йоханссон (A.-Z. Duvander, M. Johansson) [49] концептуализируют результаты социологических исследований, проведенных в северных странах ЕС (Финляндии, Исландии, Норвегии и Швеции), проверяя гипотезы, сформулированные на основе теории гендерного равенства. Включение в решение демографических проблем политики гендерного равенства привела к законодательным реформам и привлечению отцов к уходу за детьми (часть отпуска предоставляется только отцам и если данная часть не будет отцом востребована, то и мать им воспользоваться не сможет). Резервируют отпуск для отцов также в США и Канаде [53].

А.-3. Дувандер, Т. Лаппегард и М. Йоханссон (A.-Z. Duvander, T. Lappegard, M. Johansson) сравнивают интенсивность рождения в семьях, где отцы брали и не брали отпуск по уходу за ребенком [48], исследование лонгитюдное (семьи наблюдались более 10 лет) и продолжается в настоящее время. Актуальные выводы: вероятность рождения третьего ребенка в семьях, где отцом использовался отпуск, выше (в Швеции статистичес- ки подтверждено для отцов с невысоким уровнем доходов, в Норвегии - для отцов с высоким уровнем доходов), однако эффект может быть временным, если и далее семьями будет откладываться рождение первого ребенка, поэтому поиск инструментов управления данными процессами становится в данных странах приоритетным.

Обращение к исследовательским проектам других стран показывает несопоставимость начавшейся в РФ с 2000 г. демографической политики с общемировыми тенденциями. Многомерность факторов, исследуемых в разных странах [30], и их влияние на государственное управление в области семейной политики не учитываются в российском политическом поле. Тем не менее ведется поиск механизмов стабилизации экономического положения российской, в том числе молодой семьи. Во-первых, утверждена Концепция демографического развития Российской Федерации на период до 2015 г. [27]. Во-вторых, институализирован процесс обеспечения жильем молодых семей. В-третьих, начата работа по оптимизации демографических процессов в селах РФ. В-четвертых, расширяются меры социальной поддержки детей: «По результатам всероссийской диспансеризаџии детей лишь около 25 прочентов детей являются здоровыми. <..> Одной из причин такого состояния здоровья детей является отсутствие во многих семьях полноценного питания» [16]. В-пятых, разрабатываются программы социально-экономического развития Российской Федерации на среднесрочную перспективу с целью стабилизации демографической ситуации. Наконец, вносятся изменения в государственный статистический учет.

К 2008 г. фреймы официальных нормативных документов окончательно изменяются, вместо констатации негативных тенденций в программы закладываются индикаторы достижения (что повышает эффективность работы): «В связи с реализачией Кониепиии демографической политики Российской Федерации... ...ожидается улучшение демографической ситуации в 20082010 годах. <..> По среднесрочному прогнозу в 2010 году численность граждан трудоспособного возраста составит 87,6 млн человек, что на 2,6 млн человек 
(на 2,9 прочента) меньше, чем в 2006 году» [25].

В официальные документы вводятся новые структурные компоненты «Демографическая политика и политика народосбережения», уточняются целевые показатели: «Необходимо обеспечить стабилизацию численности населения на уровне не ниже 142-143 млн человек к 2015 году и создание условий для повышения к 2025 году численности населения до 145 млн человек и средней продолжительности жизни до 75 лет» [26].

В целом Правительство работает в рамках Концепции демографической политики Российской Федерации на период до 2025 г. [34]. Окончательная популяризация демографической политики - это объявление 2007 г. Годом семьи [42]. Позитивные изменения в демографической политике длились до 2015 г., в котором начался новый спад суммарного коэффициента рождаемости. С этого года начинается новый этап артикуляции демографических угроз национальной безопасности России, определяются риски, «обусловленные увеличением продолжительности жизни, изменением образа жизни, и старением населения, что приводит к новым социальным и медицинским проблемам, в том числе к росту угроз глобальных пандемий, увеличению риска появления новых и возврата исчезнувших инфекций» [35], утвержден План мероприятий по реализации в 2016-2020 гг. Концепции демографической политики Российской Федерации на период до 2025 г. [24].

Угрозы демографической безопасности России зафиксированы в Бюджетном прогнозе Российской Федерации на период до 2036 г.: «Серьезный вызов демографические изменения представляют и для государственных финансов: с одной стороны, замедление темпов экономического роста сдерживает рост налогооблагаемой базы, а с другой стороны, опережающий рост количества экономически неактивных людей старшего поколения увеличивает нагрузку на системы пенсионного и медицинского обеспечения» [28].

Результаты. Проведенный качественный анализ документов позволил выделить три этапа формирования политической повестки обсуждения демографических угроз и их влияние на безопасность Российской Федерации: 1992-1999 (период депопуляции), 2000-2014 (период демографической стабилизации), 2015-2019 (новый период демографического спада).

Разные страны используют специфические комплексы инструментов стимулирования рождаемости, так как используемые модели учитывают культуру, социально-экономические особенности региона. Обзор теоретических концепций и результаты исследований, проведенных в разных странах, показывают, что нормы демографического поведения заметно различаются на территории одной страны, в разных ее частях или в разных стратах, в семьях с разным материальным положением.

Г. Эспин-Андерсен (G. Esping-Andersen) предлагает классифицировать подходы к реализации мер демографической политики и поддержки семьи и соотнести концептуальные модели социальной политики с мерами помощи семьям в разных странах. Анализируя социальную политику в государствах всеобщего благосостояния, он выделяет следующие типы: фамилистический, либеральный, консервативный, социал-демократический [50]. Суть подхода Г. Эспин-Андерсена в том, что механизмы поддержки семей в разных странах соответствуют одной из четырех выделенных им моделей социальной политики.

При реализации социальной политики стран либерального типа (Великобритания, Ирландия) осуществляется минимальное вмешательство государства в регулирование социальных вопросов. Фактически в этом случае семья должна действовать предельно рационально, так как социальные гарантии зависят от индивидуального вклада членов семьи в систему государственного страхования, то есть учитывается трудовой стаж, размер заработной платы, страховых отчислений. Конечно, на помощь могут рассчитывать и особенно нуждающиеся граждане, однако в этом случае помощь будет минимальной.

Консервативный тип социальной политики (Бельгия, Германия, Франция, Швейцария) предлагает иные масштабы участия государства в реализации мер социальной поддержки семей. Хорошо проработанные механизмы регулирования оказания социальной помощи ориентированы не только на воспроизводство 
существующего социального порядка, но и на существенную поддержку института семьи. Размер социальных выплат также зависит от персонального «вклада» в бюджет государства (от суммы уплаченных налогов и стажа работы), но широко используются и опосредованно экономические модели помощи (инфраструктура, гибкие отпуска по уходу за ребенком и т. д.).

Наиболее благоприятной для решения демографических проблем можно назвать социал-демократическую модель социальной политики, которая осуществляется в скандинавских странах (Дания, Финляндия, Нидерланды, Норвегия, Швеция). В этих государствах обязательства по социальному обеспечению и поддержке семьи не одно десятилетие совершенствуются. В странах с социалдемократическим типом социальной политики под надзором государства наиболее оптимально осуществляется перераспределение ресурсов, что позволяет аккумулировать значительные средства на социальную политику, следовательно снимается вопрос об индивидуальном вкладе граждан в социальное обеспечение и страхование, расширяется доступ к социальным услугам.

Среди стран Западной Европы Франция имеет самый высокий коэффициент рождаемости. Сегодня в этой стране комплекс мер демографической политики один из самых прогрессивных в Европе [45]. Это, во-первых, пропаганда зарегистрированных браков. Во-вторых, ограничение доступа к абортам и к контрацепции, что неоднозначно воспринимается в социуме. В-третьих, хорошо продуманная система пособий всем категориям семей и в зависимости от уровня дохода. В-четвертых, меры, позволяющие поддерживать совмещение карьеры и материнства - ежемесячная выплата родителям, если они вынуждены взять после рождения третьего ребенка неоплачиваемый годовой отпуск; скидки, льготы и освобождение многодетных родителей от налогов; развитая инфраструктура помощи по уходу за детьми (воспитатели, врачи, психологи). В-пятых, жилищные льготы.

Не только во Франции и в современной России власти использовали жилищную политику для увеличения рождаемости. Доступные кредиты на улучшение жилищных усло- вий для молодежи (погашение $20 \%$ кредита при рождении первого ребенка; $30 \%$ - при рождении второго; оставшихся $50 \%$ - при рождении третьего) - стратегия поддержки родителей, которая позволила повысить рождаемость в ГДР в конце 1970-х годов.

Таким образом, можно сделать вывод, что политический дискурс способствует эффективному управлению в области социальной и демографической политики и детерминирует меры поддержки семей с детьми. На современном этапе развития РФ государственное управление ориентировано на формирование консервативной модели семейной политики, об этом можно судить, опираясь на поправки, внесенные в Конституцию Российской Федерации (ч. 1 ст. 72), основные положения посланий Президента РФ, принимаемые в интересах российской семьи законы, направленные на расширение мер социальной поддержки.

Подводя итог, можно констатировать, что эффективное управление позволяет обеспечить определенный рост уровня рождаемости (в РФ фиксировался до 2015 г.). Фактором роста рождаемости является «качество» жизни семьи, уверенность молодежи в будущем. Рождаемость выше в тех странах, например во Франции и в скандинавских государствах, где государственное управление в области семейной политики - это последовательно выстроенная система социальной поддержки родителей и детей, долговременная семейная политика государства, учитывающая, что современные родители пытаются совместить «конкурирующие цели»: образование, карьеру, досуг и семью, так как чувствуют потребность быть полноценными участниками жизни общества, на это направлена их система ценностей. В связи с этим в демографическую политику необходимо включать меры поддержки, позволяющие женщинам совмещать карьеру и рождение детей, что способствует гендерному равенству, а также приобщению мужчин к уходу за ребенком. Эффективность политического управления семейной политики в РФ обеспечивается следующими инструментами - материальной поддержкой семьи с детьми, ипотечным кредитованием, жилищными субсидиями, а также механизмами возврата соотечественников 
и стимулирования миграции. В современной ситуации этого недостаточно, необходимы новые инструменты решения демографических проблем и увеличения рождаемости в РФ.

\section{ПРИМЕЧАНИЕ}

${ }^{1}$ Исследование выполнено при финансовой поддержке РНФ в рамках научного проекта № 20-18-00256 «Демографическое поведение населения в контексте национальной безопасности России».

The research was carried out at the expense of the Russian Science Foundation project no. 20-18-00256 "Demographic behavior of the population in the context of national security of Russia".

\section{СПИСОК ЛИТЕРАТУРЫ}

1. Алабин, Д. В. Приоритетные национальные проекты в политическом процессе Российской Федерации: концептуальное обеспечение и технологический инструментарий : автореф. дис. ... канд. полит. наук / Алабин Дмитрий Викторович. Н. Новгород, 2009. - 22 с.

2. Архангельский, В. Н. К вопросу о семейной политике и социальной поддержке семей в Российской Федерации / В. Н. Архангельский // Семья в России. - 1994. - № 1. - С. 112-130.

3. Биткеева, А. Н. Прогнозирование и языковое многообразие в Российской Федерации: социолингвистический аспект / А. Н. Биткеева, М. Вингер, В. Ю. Михальченко // Вестник Волгоградского государственного университета. Серия 2, Языкознание. - 2019. - Т. 18, № 3. - C. 6-23. - DOI: https:// doi.org/10.15688/jvolsu2.2019.3.1

4. Вишневский, А. Г. Демографический потенциал России / А. Г. Вишневский // Вопросы экономики. - 1998. - № 5. - С. 103-122.

5. Демографическая ситуация в России: новые вызовы и пути оптимизации: национальный демографический доклад / под ред. чл.-кор. РАН, д-ра экон. наук С. В. Рязанцева. - М. : Эко-Информ, 2019. - $79 \mathrm{c}$.

6. Закон РФ «О безопасности» от 5 марта 1992 г. № 2446-I (с изм. от 25 декабря 1992 г., 24 декабря 1993 г., 25 июля 2002 г., 7 марта 2005 г., 25 июля 2006 г., 2 марта 2007 г., 26 июня 2008 г.). - Электрон. текстовые дан. - Режим доступа: http:/www.belgkh.ru/ media/site_platform_media/2018/2/24/zakon-rf-2446.pdf (дата обращения: 21.12.2020). - Загл. с экрана.

7. Захарова, О. Д. Демографическая ситуация в СССР в 80-е годы / О. Д. Захарова // Социологические исследования. - 1991. - № 4. - С. 43-52.
8. Иванова, А. Е. Прогноз здоровья взрослого населения России / А. Е. Иванова // Социологические исследования. - 1992. - № 9. - С. 50-59.

9. Красинец, Е. Демографическая ситуация в России / Е. Красинец, Н. Баринова, Е. Тюрюканова // Экономист. - 1991. - № 2. - С. 35-44.

10. Кузнецова, Е. Д. Демографическая политика Российской Федерации в контексте обеспечения национальной безопасности : автореф. дис. ... канд. полит. наук / Кузнецова Елена Дмитриевна. - Краснодар, 2012. - 27 c.

11. Постановление Государственной Думы Федерального Собрания Российской Федерации от 16.02.1996 № 90-II ГД «О мерах по обеспечению своевременности выплаты государственных пособий гражданам, имеющим детей» // Собрание Законодательства Российской Федерации. - 1996. - 26 февр. (№ 9). - Ст. 793.

12. Постановление Государственной Думы Федерального Собрания Российской Федерации от 05.12.1996 № 881-ІІ ГД «О социальной защите и поддержке семьи, детей и молодежи» // Собрание Законодательства Российской Федерации. - 1996. 16 дек. (№ 51). - Ст. 5754.

13. Постановление Государственной Думы Федерального Собрания Российской Федерации от 05.11.1998 № 3203-II ГД «Об обращении Государственной Думы Федерального Собрания Российской Федерации “К Президенту Российской Федерации в связи с принятием Всемирной декларации по здравоохранению"» // Собрание Законодательства Российской Федерации. - 1998. - 30 нояб. (№ 48). Ст. 5871.

14. Постановление Государственной Думы Федерального Собрания Российской Федерации от 02.12.1998 № 3294-ІІ ГД «О деятельности Федеральной миграционной службы России по реализации миграционной политики» // Собрание Законодательства Российской Федерации. - 1998. - 14 дек. (№ 50). - Ст. 6118.

15. Постановление Государственной Думы Федерального Собрания Российской Федерации от 22.10.1999 № 4442-ІІ ГД «О неотложных мерах по улучшению здоровья женщин и детей в Российской Федерации» // Собрание Законодательства Российской Федерации. - 1999. - 8 нояб. (№ 45). Ст. 5399.

16. Постановление Государственной Думы Федерального Собрания Российской Федерации от 18.04.2003 № 3901-III ГД «Об обращении Государственной Думы Федерального Собрания Российской Федерации “К Председателю Правительства Российской Федерации М. М. Касьянову о необходимости повышения государственных пособий гражданам, имеющим детей, и компенсационных выплат на питание обучающихся в государственных, муни- 
ципальных общеобразовательных учреждениях, учреждениях начального профессионального и среднего профессионального образования"» // Собрание Законодательства Российской Федерации. 2003. - 5 мая (№ 18). - Ст. 1680.

17. Постановление Правительства Российской Федерации от 03.08.1996 № 935 «Об уточнении Федеральной миграционной программы» // Собрание Законодательства Российской Федерации. 1996. - 26 авг. (№ 35). - Ст. 4177.

18. Постановление Правительства Российской Федерации от 26.02.1997 № 222 «О Программе социальных реформ в Российской Федерации на период 1996-2000 годов» // Собрание Законодательства Российской Федерации. - 1997. - 10 марта (№ 10). - СТ. 1173.

19. Постановление Правительства Российской Федерации от 28.06.1996 № 762 «Об утверждении Федеральной комплексной программы развития малых и средних городов Российской Федерации в условиях экономической реформы» // Собрание Законодательства Российской Федерации. - 1996. 9 сент. (№ 37).

20. Постановление Правительства Российской Федерации от 31.03.1997 № 360 «Об угверждении программы Правительства Российской Федерации “Структурная перестройка и экономический рост в 1997-2000 годах”» // Собрание Законодательства Российской Федерации. - 1997. - 12 мая (№ 19). - Ст. 2230.

21. Постановление Правительства Российской Федерации от 06.05.1994 № 474 «Об утверждении Основных направлений социальной политики Правительства Российской Федерации на 1994 год» // Собрание Законодательства Российской Федерации. - 1994. - 23 мая (№ 4). - Ст. 363.

22. Постановление Совета Министров - Правительства РФ от 23.07.1993 № 697 «Об утверждении Положения о Межведомственной комиссии по социально-демографическим вопросам» // Собрание Актов Президента и Правительства Российской Федерации. - 1993. - 2 авг. (№ 31). - Ст. 2846.

23. Путин, В. В. Послание Федеральному Собранию Российской Федерации. 8 июля 2000 г. / В. В. Путин. - Электрон. текстовые дан. - Режим доступа: http:/www.consultant.ru/document/ cons_doc_LAW_27823/\#dst0 (дата обращения: 08.08.2020). - Загл. с экрана.

24. Распоряжение Правительства Российской Федерации от 14.04.2016 № 669-р «Об Утверждении Плана мероприятий по реализации в 2016-2020 годах Концепции демографической политики Российской Федерации на период до 2025 года» // Собрание Законодательства Российской Федерации. 2016. - 25 апр. (№ 17). - Ст. 2426.

25. Распоряжение Правительства Российской Федерации от 15.08.2008 № 1193-р «Об одобрении
Концепции действий на рынке труда на 2008-2010 годы» // Собрание Законодательства Российской Федерации. - 2008. - 25 авг. (№ 34). - Ст. 3964.

26. Распоряжение Правительства Российской Федерации от 17.11.2008 № 1662-р «Об утверждении Концепции долгосрочного социально-экономического развития Российской Федерации на период до 2020 года» // Собрание Законодательства Российской Федерации. - 2008. - 24 нояб. (№ 47). Ст. 5489.

27. Распоряжение Правительства Российской Федерации от 24.09.2001 № 1270-р «Об одобрении Концепции демографического развития Российской Федерации на период до 2015 года» // Собрание Законодательства Российской Федерации. 2001. - 1 окт. (№ 40). - Ст. 3873.

28. Распоряжение Правительства Российской Федерации от 29.03.2019 № 558-р «Об утверждении Бюджетного прогноза Российской Федерации на период до 2036 года» // Собрание Законодательства Российской Федерации. - 2019. - 8 апр. (№ 14, ч. I-IV). - Ст. 1602.

29. Распоряжение Правительства Российской Федерации от 29.08.2000 № 1193-р «Об утверждении Концепции охраны здоровья населения Российской Федерации на период до 2005 года» // Собрание Законодательства Российской Федерации. 2000. - 11 сент. (№ 37). - Ст. 3734.

30. Сулейманлы, А. Оценка уровня счастья в Евразийских странах в контексте результатов Всемирного Индекса Счастья / А. Сулейманлы // Международные отношения и диалог культур. - 2020. № 8. - С. 181-195.

31. Указ Президента Российской Федерации № 1922 от 15.09.1994 «О федеральной программе “Молодежь России”» // Гарант. - Электрон. текстовые дан. - Режим доступа: http://base.garant.ru/1548736 (дата обращения: 25.08.2020). - Загл. с экрана.

32. Указ Президента Российской Федерации от 03.06.1996 № 803 «Об Основных положениях региональной политики в Российской Федерации» // Coбрание Законодательства Российской Федерации. 1996. - 3 июня (№ 23). - Ст. 2756.

33. Указ Президента Российской Федерации от 09.08.1994 № 1668 «О Федеральной миграционной программе» // Собрание Законодательства Российской Федерации. - 1994. - 29 авг. (№ 18). - Ст. 2065.

34. Указ Президента Российской Федерации от 09.10.2007 № 1351 «Об утверждении Концепции демографической политики Российской Федерации на период до 2025 года» // Собрание Законодательства Российской Федерации. -2007. - 15 окт. (№ 42). - Ст. 5009.

35. Указ Президента Российской Федерации от 01.12.2016 № 642 «Об Утверждении Стратегии научно-технологического развития Российской Феде- 
рации» // Собрание Законодательства Российской Федерации. - 2016. - 5 дек. (№ 49). - Ст. 6887.

36. Указ Президента Российской Федерации от 10.01.2000 № 24 «О Концепции национальной безопасности Российской Федерации» // Собрание Законодательства Российской Федерации. - 2000. 10 янв. (№ 2). - Ст. 170.

37. Указ Президента Российской Федерации от 14.05.1996 № 712 «Об Основных направлениях государственной семейной политики» // Собрание Законодательства Российской Федерации. - 1996. 20 мая (№ 21). - Ст. 2460.

38. Указ Президента Российской Федерации от 15.11.1993 № 1908 «О Комиссии по вопросам женщин, семьи и демографии при Президенте Российской Федерации» // Собрание актов Президента и Правительства Российской Федерации. - 1993. 22 нояб. (№ 47). - Ст. 4524.

39. Указ Президента Российской Федерации от 19.02.1996 № 210 «О продлении действия президентской программы “Дети России”» // Собрание Законодательства Российской Федерации. - 1996. 26 февр. (№ 9). - Ст. 799.

40. Указ Президента Российской Федерации от 29.03.1996 № 431 «О новом этапе реализации Государственной целевой программы “Жилище”») // Coбрание Законодательства Российской Федерации. 1996. - 1 апр. (№ 14). - Ст. 1431.

41. Указ Президента Российской Федерации от 31.12.2015 № 683 «О Стратегии национальной безопасности Российской Федерации» // Официальный сайт Президента РФ. - Электрон. текстовые дан. Режим доступа: http://www.kremlin.ru/acts/bank/ 40391 (дата обращения: 22.12.2020). - Загл. с экрана.

42. Указ Президента Российской Федерации от 14.06.2007 № 761 «О проведении в Российской Федерации Года семьи» // Собрание Законодательства Российской Федерации. - 2007. - 18 июня (№ 25). Ст. 3009.

43. Федеральный Закон «О федеральном бюджете на 1994 год» (в редакции федеральных законов от 23.12.94 № 75-Ф3; от 31.03.95 № 39-Ф3). - Электрон. текстовые дан. - Режим доступа: http:// pravo.gov.ru/proxy/ips/?docbody $=\&$ prevDoc $=$ 102031896\&backlink=1\&\&nd=102030996 (дата обращения: 25.08.2020). - Загл. с экрана.

44. Харченко, М. А. Демографические процессы как угроза и условие обеспечения национальной безопасности Российской Федерации : автореф. дис. ... канд. полит. наук / Харченко Максим Александрович. - Ставрополь, 2008.

45. Чистякова, А. Франции нужны дети. Политика пронатализма во Франции / А. Чистякова // Демоскоп Weekly. - 2009. - № 377-378. Электрон. текстовые дан. - Режим доступа: http:// www.demoscope.ru/weekly/2009/037 7 / student03.php (дата обращения: 11.08. 2020). Загл. с экрана.

46. Beaujouan, E. The Gap Between Lifetime Fertility Intentions and Completed Fertility in Europe and the United States: A Cohort Approach / E. Beaujouan, C. Berghammer // Population Research and Policy Review. - 2019. - № 38. - P. 507-535. DOI: https://doi.org/10.1007/s11113-019-09516-3.

47. Beaujouan, E. Is the Family Size of Parents and Children Still Related? Revisiting the Cross-Generational Relationship Over the Last Century / E. Beaujouan, A. Solaz// Demography. - 2019. - № 56. -P. 595-619.DOI: https://doi.org/10.1007/s13524-019-00767-5.

48. Duvander, A. Impact of a Reform Towards Shared Parental Leave on Continued Fertility in Norway and Sweden / A. Duvander, T. Lappegard, M. Johansson // Population Research and Policy Review. - 2020. - № 39. - P. 1205-1229. - DOI: https:// doi.org/10.1007/s11113-020-09574-y.

49. Duvander, A.-Z. Does Fathers' Care Spill Over? Evaluating Reforms in the Swedish Parental Leave Program / A.-Z. Duvander, M. Johansson // Feminist Economics. - 2019. - № 25:2. - P. 67-89. - DOI: https:// doi.org/10.1080/13545701.2018.1474240.

50. Esping-Andersen, G. The Three Worlds of Welfare Capitalism / G. Esping-Andersen. Cambridge : Polity Press, 1990. - P. 9-54.

51. Lebano, A. Childbearing in Italy and Spain: Postponement Narratives / A. Lebano, L. Jamieson // Population and Development Review. - 2020. № 46 (1). - P. 121-144.

52. National Audit Office. Entitlement to free early education and childcare. London: Department for Education (Report HC 853), 2016. - Электрон. текстовые дан. - Режим доступа: https://www.nao.org.uk/ wp-content/uploads/2016/03/Entitlement-to-freeearly-education-and-childcare.pdf (дата обращения: 19.08. 2020). - Загл. с экрана.

53. Rehel, Erin M. When Dad Stays Home Too: Paternity Leave, Gender, and Parenting / Erin M. Rehel // Gender \& Society. - 2014. - № 28 (1). - P. 110-132.

54. Zhou, M. ANew Family Equilibrium? Changing Dynamics Between the Gender Division of Labor and Fertility in Great Britain, 1991-2017 / M. Zhou, M. Y. Kan // Demographic Research. - 2019. - № 40:50. P. $1455-1500$.

\section{REFERENCES}

1. Alabin D.V. Prioritetnyye natsionalnyye proyekty $v$ politicheskom protsesse Rossiyskoy Federatsii: kontseptualnoye obespecheniye $i$ tekhnologicheskiy instrumentariy: avtoref. dis. ... kand. polit. nauk [Priority National Projects in the Political Process of the Russian Federation: Conceptual 
Support and Technological tools. Cand. polit. sci. abs. diss.]. Nizhny Novgorod, 2009. 22 p.

2. Arhangel'skij V.N. K voprosu o semejnoj politike i social'noj podderzhke semej v Rossijskoj Federacii [On the Issue of Family Policy and Social Support for Families in the Russian Federation]. Sem 'ja $v$ Rossii [Family in Russia], 1994, no. 1, pp. 112-130.

3. Bitkeeva A.N., Wingender M., Mikhalchenko V.Yu. Prognozirovanie i yazykovoe mnogoobrazie v Rossijskoj Federacii: sociolingvisticheskij aspekt [Language Prognosis and Language Diversity in the Russian Federation: Sociolinguistic Aspect]. Vestnik Volgogradskogo gosudarstvennogo universiteta. Seriya 2. Yazykoznanie [Science Journal of Volgograd State University. Linguistics], 2019, vol. 18, no. 3, pp. 6-23. DOI: https://doi.org/10.15688/jvolsu2.2019.3.1

4. Vishnevskij A.G. Demograficheskij potencial Rossii [Demographic Potential of Russia]. Voprosy ekonomiki [Economic Issues], 1998, no. 5, pp. 103-122.

5. Demograficheskaya situaciya $v$ Rossii: novye vyzovy $i$ puti optimizacii: nacional'nyj demograficheskij doklad [Demographic Situation in Russia: New Challenges and Ways of Optimization: National Demographic Report]. Moscow, Iz-vo EkoInform, 2019. $79 \mathrm{p}$.

6. Zakon $R F$ «O bezopasnosti» ot 5 marta 1992 g. № 2446-I (s izmeneniyami) [Law of the Russian Federation "On Security” of March 5, 1992, no. 2446-I (As Amended)]. URL: http://www.belgkh.ru/ media/site_platform_media/2018/2/24/zakon-rf2446.pdf(accessed 21 December 2020).

7. Zaharova O.D. Demograficheskaya situaciya v SSSR v 80-e gody [Demographic Situation in the USSR in the 80s]. Sociologicheskie issledovaniya [Sociological Research], 1991, no. 4, pp. 43-52.

8. Ivanova A.E. Prognoz zdorov'ya vzroslogo naseleniya Rossii [Prognosis of Health of the Adult Population of Russia]. Sociologicheskie issledovaniya [Sociological Research], 1992, no. 9, pp. 50-59.

9. Krasinec E., Barinova N., Tyuryukanova E. Demograficheskaya situaciya v Rossii [Demographic Situation in Russia]. Ekonomist [Economist], 1991, no. 2, pp. 35-44.

10. Kuznetsova E.D. Demograficheskaya politika Rossiyskoy Federatsii v kontekste obespecheniya natsionalnoy bezopasnosti: avtoref. dis. ... kand. polit. nauk [Demographic Policy of the Russian Federation in the Context of Ensuring National Security. Cand. polit. sci. abs. diss.]. Krasnodar, 2012. 27 p.

11. Postanovlenie Gosudarstvennoj Dumy Federal'nogo Sobraniya Rossijskoj Federacii ot 16.02.1996 g. № 90-II GD «O merah po obespecheniyu svoevremennosti vyplaty gosudarstvennyh posobij grazhdanam, imeyushchim detej» [Resolution of the State Duma of the Federal Assembly of the Russian Federation of 16.02.1996 No. 90-II of the State Duma
"On Measures to Ensure the Timely Payment of State Benefits to Citizens with Children"]. Sobranie Zakonodatel 'stva Rossijskoj Federacii [Collection of Legislation of the Russian Federation], 1996, Feb. 26 (no. 9), art. 793.

12. Postanovlenie Gosudarstvennoj Dumy Federal'nogo Sobraniya Rossijskoj Federacii ot 05.12 .1996 g. № 881-II GD «O social’noj zashchite i podderzhke sem'i, detej i molodezhi» [The Resolution of the State Duma of the Federal Assembly of the Russian Federation dated 05.12.1996 No. 881-II GD “On Social Security and Family Support, Children and Young People"]. Sobranie Zakonodatel'stva Rossijskoj Federacii [Collection of Legislation of the Russian Federation], 1996, Dec. 16 (no. 51), art. 5754.

13. Postanovlenie Gosudarstvennoj Dumy Federal'nogo Sobraniya Rossijskoj Federacii ot 05.11.1998 g. №3203-II GD «Ob obrashchenii Gosudarstvennoj Dumy Federal'nogo Sobraniya Rossijskoj Federacii “K Prezidentu Rossijskoj Federacii $\mathrm{V}$ svyazi s prinyatiem Vsemirnoj deklaracii po zdravoohraneniyu"» [The Resolution of the State Duma of the Federal Assembly of the Russian Federation of 05.11.1998, №3203-II GD “On Circulation of the State Duma of the Federal Assembly of the Russian Federation 'To the President of the Russian Federation in Connection with Adoption of the World Declaration on Public Health" "]. Sobranie Zakonodatel'stva Rossijskoj Federacii [Collection of Legislation of the Russian Federation], 1998, Nov. 30 (no. 48), art. 5871.

14. Postanovlenie Gosudarstvennoj Dumy Federal'nogo Sobraniya Rossijskoj Federacii ot 02.12.1998 g. №3294-II GD «O deyatel’nosti Federal’noj migracionnoj sluzhby Rossii po realizacii migracionnoj politiki» [The Resolution of the State Duma of the Federal Assembly of the Russian Federation Dated 02.12.1998, No. 3294-II GD "On the Activities of the Federal Migration Service of Russia on Realization of Migration Policy"]. Sobranie Zakonodatel'stva Rossijskoj Federacii [Collection Legislation of the Russian Federation], 1998, Dec. 14 (no. 50), art. 6118.

15. Postanovlenie Gosudarstvennoj Dumy Federal'nogo Sobraniya Rossijskoj Federacii ot 22.10.1999 g. № 4442-II GD «O neotlozhnyh merah po uluchsheniyu zdorov'ya zhenshchin i detej v Rossijskoj Federacii»» [Resolution of the State Duma of the Federal Assembly of the Russian Federation No. 4442-II of the State Duma of 22.10.1999 “On Urgent Measures to Improve the Health of Women and Children in the Russian Federation"]. Sobranie Zakonodatel'stva Rossijskoj Federacii [Collection of Legislation of the Russian Federation], 1999, Nov. 8 (no. 45), art. 5399.

16. Postanovlenie Gosudarstvennoj Dumy Federal'nogo Sobraniya Rossijskoj Federacii ot 18.04.2003 g. № 3901-III GD «Ob obrashchenii Gosudarstvennoj Dumy Federal'nogo Sobraniya 
Rossijskoj Federacii “K Predsedatelyu Pravitel'stva Rossijskoj Federacii M.M. Kas'yanovu o neobhodimosti povysheniya gosudarstvennyh posobij grazhdanam, imeyushchim detej, i kompensacionnyh vyplat na pitanie obuchayushchihsya v gosudarstvennyh, municipal'nyh obshcheobrazovatel'nyh uchrezhdeniyah, uchrezhdeniyah nachal'nogo professional'nogo i srednego professional'nogo obrazovaniya"» [Resolution of the State Duma of the Federal Assembly of the Russian Federation of 18.04.2003 No. 3901-III GD “On Circulation of the State Duma of the Federal Assembly of the Russian Federation 'The Chairman of the Government of the Russian Federation M.M. Kasyanov on the Need to Increase State Allowances to Citizens with Children, and Compensation for Meals of Students of State, Municipal General Educational Institutions, Institutions of Primary Vocational and Secondary Vocational Education" "]. Sobranie Zakonodatel'stva Rossijskoj Federacii [Collection of Legislation of the Russian Federation], 2003, May 5 (no. 18), art. 1680.

17. Postanovlenie Pravitel'stva Rossijskoj Federacii ot 03.08.1996 g. № 935 «Ob utochnenii Federal'noj migracionnoj programmy» [Resolution of the Government of the Russian Federation No. 935 of 03.08.1996 "On the Clarification of the Federal Migration Program"]. Sobranie Zakonodatel'stva Rossijskoj Federacii [Collection of legislation of the Russian Federation], 1996, Aug. 26 (no. 35), art. 4177.

18. Postanovlenie Pravitel'stva Rossijskoj Federacii ot 26.02.1997 g. № 222 «O Programme social'nyh reform v Rossijskoj Federacii na period 1996-2000 godov» [Resolution of the Government of the Russian Federation No. 222 of 26.02.1997 “On the Program of Social Reforms in the Russian Federation for the Period 1996-2000"]. Sobranie Zakonodatel'stva Rossijskoj Federacii [Collection of Legislation of the Russian Federation], 1997, Mar. 10 (no. 10), art. 1173.

19. Postanovlenie Pravitel'stva Rossijskoj Federacii ot 28 iyunya 1996 g. № $762 \ll \mathrm{Ob}$ utverzhdenii Federal'noj kompleksnoj programmy razvitiya malyh i srednih gorodov Rossijskoj Federacii v usloviyah ekonomicheskoj reformy» [Resolution of the Government of the Russian Federation No. 762 of June 28, 1996 "On the Approval of the Federal Comprehensive Program for the Development of Small and Medium-Sized Cities of the Russian Federation in the Context of Economic Reform"]. Sobranie Zakonodatel'stva Rossijskoj Federacii [Collection of Legislation of the Russian Federation], 1996, Sept. 9 (no. 37).

20. Postanovlenie Pravitel'stva Rossijskoj Federacii ot 31.03.1997 g. № 360 «Ob utverzhdenii programmy Pravitel'stva Rossijskoj Federacii
"Strukturnaya perestrojka i ekonomicheskij rost v 1997-2000 godah"» [Resolution of the Government of the Russian Federation, No. 360 of 31.03.1997 "On the Approval of the Program of the Government of the Russian Federation 'Structural Restructuring and Economic Growth in 1997-2000" "]. Sobranie Zakonodatel'stva Rossijskoj Federacii [Collection of Legislation of the Russian Federation], 1997, May 12 (no. 19), art. 2230.

21. Postanovlenie Pravitel'stva Rossijskoj Federacii ot 6 maya 1994 g. № 474 «Ob utverzhdenii Osnovnyh napravlenij social'noj politiki Pravitel'stva Rossijskoj Federacii na 1994 god» [Resolution of the Government of the Russian Federation of May 6, 1994 N 474 "On Approval of the Main Directions of the Social Policy of the Government of the Russian Federation for 1994"]. Sobranie Zakonodatel'stva Rossijskoj Federacii [Collection of Legislation of the Russian Federation], 1994, May 23 (no. 4), art. 363.

22. Postanovlenie Soveta Ministrov Pravitel'stva RF ot 23 iyulya 1993 g. № 697 «Ob utverzhdenii Polozheniya o Mezhvedomstvennoj komissii po social'no-demograficheskim voprosam» [Resolution of the Council of Ministers-Government of the Russian Federation of July 23, 1993 No. 697 "On Approval of the Regulations on the Interdepartmental Commission on Socio-Demographic Issues"]. Sobranie Aktov Prezidenta i Pravitel'stva Rossijskoj Federacii [Collection of Acts of the President and Government of the Russian Federation], 1993, Aug. 2 (no. 31), art. 2846.

23. Putin V.V. Poslanie Federal'nomu Sobraniyu Rossijskoj Federacii. 8 iyulya $2000 \mathrm{~g}$. [Message to the Federal Assembly of the Russian Federation]. URL: http://www.consultant.ru/document/cons _doc_LAW_27823/\#dst0 (accessed 8 August 2020).

24. Rasporyazhenie Pravitel'stva Rossijskoj Federacii ot 14 aprelya 2016 g. № 669-r «Ob Utverzhdenii Plana meropriyatij po realizacii v 20162020 godah Koncepcii demograficheskoj politiki Rossijskoj Federacii na period do 2025 goda» [Order of the Government of the Russian Federation of April 14, 2016 N 669-r "On Approval of the Action Plan for the Implementation in 2016-2020 of the Concept of Demographic Policy of the Russian Federation for the period up to 2025"]. Sobranie Zakonodatel'stva Rossijskoj Federacii [Collection Legislation of the Russian Federation], 2016, Apr. 25 (no. 17), art. 2426.

25. Rasporyazhenie Pravitel'stva Rossijskoj Federacii ot 15 avgusta 2008 g. № 1193-r «Ob odobrenii Koncepcii dejstvij na rynke truda na 2008-2010 gody» [Order of the Government of the Russian Federation of August 15, 2008 No. 1193-r "On Approval of the Concept of Actions on the Labor Market for 2008-2010"]. Sobranie Zakonodatel'stva Rossijskoj Federacii 
[Collection of Legislation of the Russian Federation], 2008, Aug. 25 (no. 34), art. 3964.

26. Rasporyazhenie Pravitel'stva Rossijskoj Federacii ot 17 noyabrya 2008 g. № 1662-r «Ob utverzhdenii Koncepcii dolgosrochnogo social'no-ekonomicheskogo razvitiya Rossijskoj Federacii na period do 2020 goda» [Order of the Government of the Russian Federation of November 17, 2008 No. 1662-r "On Approval of the Concept of Long-Term Socio-Economic Development of the Russian Federation for the Period up to 2020"]. Sobranie Zakonodatel'stva Rossijskoj Federacii [Collection of Legislation of the Russian Federation], 2008, Nov. 24 (no. 47), art. 5489.

27. Rasporyazhenie Pravitel'stva Rossijskoj Federacii ot 24.09.2001 g. № 1270-r «Ob odobrenii Koncepcii demograficheskogo razvitiya Rossijskoj Federacii na period do 2015 goda» [Order of the Government of the Russian Federation No. 1270-r of 24.09.2001 "On Approval of the Concept of Demographic Development of the Russian Federation for the Period up to 2015"']. Sobranie Zakonodatel 'stva Rossijskoj Federacii [Collection of Legislation of the Russian Federation], 2001, Oct. 1 (no. 40), art. 3873.

28. Rasporyazhenie Pravitel'stva Rossijskoj Federacii ot 29 marta 2019 g. № 558-r «Ob utverzhdenii Byudzhetnogo prognoza Rossijskoj Federacii na period do 2036 goda» [Order of the Government of the Russian Federation No. 558-r of March 29, 2019 "On Approval of the Budget Forecast of the Russian Federation for the Period up to 2036"]. Sobranie Zakonodatel'stva Rossijskoj Federacii [Collection of Legislation of the Russian Federation], 2019, Apr. 8 (no. 14, pt. I-IV), art. 1602.

29. Rasporyazhenie Pravitel'stva Rossijskoj Federacii ot 29.08.2000 g. № 1193-r «Ob utverzhdenii Koncepcii ohrany zdorov'ya naseleniya Rossijskoj Federacii na period do 2005 goda» [Order of the Government of the Russian Federation No. 1193-r of 29.08.2000 "On the Approval of the Concept of Public Health Protection of the Russian Federation for the Period up to 2005"]. Sobranie Zakonodatel'stva Rossijskoj Federacii [Collection of Legislation of the Russian Federation], 2000, Sept. 11 (no. 37), art. 3734.

30. Suleymanlı E. Ocenka urovnya schast'ya v Evrazijskih stranah v kontekste rezul'tatov Vsemirnogo Indeksa Schast'ya [The Happiness Level Assessment in the Eurasian Countries in the Context of the World Happiness Index Results]. Internatıonal Relations and Dialogue of Cultures, 2020, no. 8, pp.181-195.

31. Ukaz Prezidenta Rossijskoj Federacii № 1922 ot 15 sentyabrya 1994 goda O federal'noj programme «Molodezh' Rossii» [Decree of the President of the Russian Federation No. 1922 of September 15, 1994 on the Federal Program "Youth of Russia"]. Garant
[Garant]. URL: http://base.garant.ru/1548736/ (accessed 25 August 2020).

32. Ukaz Prezidenta Rossijskoj Federacii ot 03.06.1996 g. № $803 \mathrm{Ob}$ Osnovnyh polozheniyah regional'noj politiki v Rossijskoj Federacii [Decree of the President of the Russian Federation No. 803 of 03.06.1996 "On the Main Provisions of Regional Policy in the Russian Federation"]. Sobranie Zakonodatel'stva Rossijskoj Federacii [Collection of Legislation of the Russian Federation], 1996, June 3 (no. 23), art. 2756.

33. Ukaz Prezidenta Rossijskoj Federacii ot 09.08.1994 g. № 1668 «O Federal’noj migracionnoj programme» [Decree of the President of the Russian Federation No. 1668 of 09.08.1994 "On the Federal Migration Program"]. Sobranie Zakonodatel'stva Rossijskoj Federacii [Collection of Legislation of the Russian Federation], 1994, Aug. 29 (no. 18), art. 2065.

34. Ukaz Prezidenta Rossijskoj Federacii ot 09.10.2007 g. № 1351 Ob utverzhdenii Koncepcii demograficheskoj politiki Rossijskoj Federacii na period do 2025 goda [Decree of the President of the Russian Federation No. 1351 of 09.10.2007 “On the Approval of the Concept of Demographic Policy of the Russian Federation for the Period up to 2025]. Sobranie Zakonodatel'stva Rossijskoj Federacii [Collection of Legislation of the Russian Federation], 2007, Oct. 15 (no. 42), art. 5009.

35. Ukaz Prezidenta Rossijskoj Federacii ot 1 dekabrya 2016 g. № 642 «Ob Utverzhdenii Strategii nauchno-tekhnologicheskogo razvitiya Rossijskoj Federacii» [Decree of the President of the Russian Federation No. 642 of December 1, 2016 "On the Approval of the Strategy of scientific and Technological Development of the Russian Federation"]. Sobranie Zakonodatel'stva Rossijskoj Federacii [Collection of Legislation of the Russian Federation], 2016, Dec. 5 (no. 49), art. 6887.

36. Ukaz Prezidenta Rossijskoj Federacii ot 10.01.2000 g. № 24 «O Koncepcii nacional’noj bezopasnosti Rossijskoj Federacii» [Decree of the President of the Russian Federation No. 24 of 10.01.2000 "On the Concept of National Security of the Russian Federation"]. Sobranie Zakonodatel'stva Rossijskoj Federacii [Collection of Legislation of the Russian Federation], 2000, Jan. 10 (no. 2), art. 170.

37. Ukaz Prezidenta Rossijskoj Federacii ot 14.05 .1996 g. № 712 «Ob Osnovnyh napravleniyah gosudarstvennoj semejnoj politiki» [Decree of the President of the Russian Federation No. 712 of 14.05.1996 "On the Main Directions of the State Family Policy”]. Sobranie Zakonodatel'stva Rossijskoj Federacii [Collection of Legislation of the Russian Federation], 1996, May 20 (no. 21), art. 2460.

38. Ukaz Prezidenta Rossijskoj Federacii ot 15.11 .1993 g. № 1908 «O Komissii po voprosam zhenshchin, sem'i i demografii pri Prezidente Rossijskoj 
Federacii [Decree of the President of the Russian Federation No. 1908 of 15.11 .1993 “On the Commission on Women, Family and Demography Under the President of the Russian Federation"]. Sobranie aktov Prezidenta i Pravitel 'stva Rossijskoj Federacii [Collection of Acts of the President and the Government of the Russian Federation], 1993, Nov. 22 (no. 47), art. 4524.

39. Ukaz Prezidenta Rossijskoj Federacii ot 19.02.1996 g. № 210 «O prodlenii dejstviya prezidentskoj programmy "Deti Rossii"» [Decree of the President of the Russian Federation No. 210 of 19.02.1996 "On the Extension of the Presidential Program 'Children of Russia' "]. Sobranie Zakonodatel'stva Rossijskoj Federacii [Collection of Legislation of the Russian Federation], 1996, Feb. 26 (no. 9), art. 799.

40. Ukaz Prezidenta Rossijskoj Federacii ot 29.03 .1996 g. № 431 «O novom etape realizacii Gosudarstvennoj celevoj programmy "ZHilishche"» [Decree of the President of the Russian Federation No. 431 of 29.03.1996 "On the New Stage of Implementation of the State Target Program 'Housing' "]. Sobranie Zakonodatel'stva Rossijskoj Federacii [Collection of Legislation of the Russian Federation], 1996, Apr. 1 (no. 14), art. 1431.

41. Ukaz Prezidenta Rossiyskoy Federatsii ot 31 dekabrya 2015 goda № 683 «O Strategii natsionalnoy bezopasnosti Rossiyskoy Federatsii» [Decree of the President of the Russian Federation No. 683 of December 31, 2015 "On the National Security Strategy of the Russian Federation"]. URL: http://www.kremlin.ru/acts/bank/40391 (accessed 22 December 2020).

42. Ukaz Prezidenta Rossijskoj Federacii ot 14 iyunya 2007 g. № 761 «O provedenii v Rossijskoj Federacii Goda sem'i» [Decree of the President of the Russian Federation of June 14, 2007 No. 761 "On holding the Year of the Family in the Russian Federation"]. Sobranie Zakonodatel'stva Rossijskoj Federacii [Collection of Legislation of the Russian Federation], 2007, June 18 (no. 25), art. 3009.

43. Federal'nyj Zakon O federal'nom byudzhete na 1994 god Prinyat Gosudarstvennoj Dumoj 24 iyunya 1994 goda Odobren Sovetom Federacii 24 iyunya 1994 goda. V redakcii federal'nyh zakonov ot 23.12.94 g. N 75-FZ; ot 31.03.95 g. N 39-FZ [The Federal Law on the Federal Budget for 1994 Was Adopted by the State Duma on June 24, 1994 and Approved by the Federation Council on June 24, 1994 as Amended by Federal Laws No. 75-FZ of 23.12.94; No. 39-FZ of 31.03.95. As amended by Federal Laws No. 75FZ of 23.12.94; No. 39-FZ of 31.03.95]. URL: http:// pravo.gov.ru/proxy/ips/?docbody $=\&$ prevDoc $=$
$102031896 \&$ backlink=1\&\&nd=102030996 (accessed 25 August 2020).

44. Kharchenko M.A. Demograficheskiye protsessy kak ugroza i usloviye obespecheniya natsionalnoy bezopasnosti Rossiyskoy Federatsii: avtoref. dis. ... kand. polit. nauk [Demographic Processes as a Threat and Condition for Ensuring the National Security of the Russian Federation. Cand. polit. sci. abs. diss.]. Stavropol, 2008.

45. Chistyakova A. Francii nuzhny deti. Politika pronatalizma vo Francii [France Needs Children. The Politics of Pronatalism in France]. Demoskop Weekly [Demoscope Weekly], 2009, no. 377-378. URL: http:// www.demoscope.ru/weekly/2009/0377/student03.php (accessed 11 August 2020).

46. Beaujouan E., Berghammer C. The Gap Between Lifetime Fertility Intentions and Completed Fertility in Europe and the United States: A Cohort Approach. Population Research and Policy Review, 2019, no. 38, pp. 507-535. DOI: https://doi.org/10.1007/ s11113-019-09516-3.

47. Beaujouan E., Solaz A. Is the Family Size of Parents and Children Still Related? Revisiting the Cross-Generational Relationship Over the Last Century. Demography, 2019, no. 56, pp. 595-619. DOI: https://doi.org/10.1007/s13524-019-00767-5.

48. Duvander A., Lappegard T., Johansson M. Impact of a Reform Towards Shared Parental Leave on Continued Fertility in Norway and Sweden. Population Research and Policy Review, 2020, no. 39, pp. 1205-1229. DOI: https://doi.org/10.1007/s11113020-09574-y.

49. Duvander A.-Z., Johansson M. Does Fathers' Care Spill Over? Evaluating Reforms in the Swedish Parental Leave Program. Feminist Economics, 2019, № 25:2, pp. 67-89. DOI: https://doi.org/10.1080/ 13545701.2018.1474240.

50. Esping-Andersen G. The Three Worlds of Welfare. Cambridge, Polity Press, 1990, pp. 9-54.

51. Lebano A., Jamieson L. Childbearing in Italy and Spain: Postponement Narratives. Population and Development Review, 2020, no. 46 (1), pp. 121-144.

52. National Audit Office. Entitlement to Free Early Education and Childcare. Department for Education. Report HC 853, 2016, London. URL: https:/ /www.nao.org.uk/wp-content/uploads/2016/03/ Entitlement-to-free-early-education-and-childcare.pdf (accessed 19 August 2020).

53. Rehel, Erin M. When Dad Stays Home Too: Paternity Leave, Gender, and Parenting. Gender \& Society, 2014, no. 28 (1), pp. 110-132.

54. Zhou M., Kan M.Y. A New Family Equilibrium? Changing Dynamics Between the Gender Division of Labor and Fertility in Great Britain, 1991-2017. Demographic research, 2019, no. 40:50, pp. $1455-1500$. 


\section{Information About the Authors}

Ekaterina N. Vasilieva, Doctor of Sciences (Sociology), Associate Professor, Professor, Department of Sociology and Social Technologies, Volgograd State University, Prosp. Universitetsky, 100, 400062 Volgograd, Russian Federation, vasilevaen@volsu.ru, https://orcid.org/0000-0002-0460-5539

Tamara K. Rostovskaya, Doctor of Sciences (Sociology), Professor, Deputy Director for Research, Institute for Demographic Research of the Federal Center of Theoretical and Applied Sociology of the Russian Academy of Sciences, Fotievoy St, 6, Bld. 1, 119333 Moscow, Russian Federation, rostovskaya.tamara@mail.ru, https://orcid.org/0000-0002-1629-7780

Ebulfez Süleymanlý, Doctor of Sciences (Sociology), Professor, Head of the Department of Sociology, Üsküdar University, Haluk Türksoy St, 14, 34662 Istanbul, Turkey, ebulfez.suleymanli@uskudar.edu.tr, https://orcid.org/0000-0003-1894-5232

\section{Информация об авторах}

Екатерина Николаевна Васильева, доктор социологических наук, доцент, профессор кафедры социологии и социальных технологий, Волгоградский государственный университет, просп. Университетский, 100, 400062 г. Волгоград, Российская Федерация, vasilevaen@volsu.ru, https://orcid.org/0000-0002-0460-5539

Тамара Керимовна Ростовская, доктор социологических наук, профессор, заместитель директора по научной работе, Институт демографических исследований ФНИСЦ РАН, ул. Фотиевой, 6, корп. 1, 119333 г. Москва, Российская Федерация, rostovskaya.tamara@mail.ru, https://orcid.org/0000-0002-1629-7780

Абульфаз Сулейманлы, доктор социологических наук, профессор, заведующий кафедрой социологии, Ускюдарский университет, ул. Халук Тюрксой, 14, 34662 г. Стамбул, Турция, ebulfez.suleymanli@uskudar.edu.tr, https://orcid.org/0000-0003-1894-5232 